\title{
Structure and Mechanical Properties of Spheroidal Graphite Cast Iron with Nanosized Additives
}

\author{
Julieta Kaleicheva', Valentin Mishev', Zdravka Karaguiozova², Galina Nikolcheva1 \\ ${ }^{1}$ Technical University of Sofia, boulevard Kliment Ohridski 8, 1000 Sofia, Bulgaria, \\ e-mail: jkaleich@tu-sofia.bg \\ ${ }^{2}$ Space Research and Technology Institute, Bulgarian Academy of Sciences, Acad. G. Bonchev str., B1.1, \\ Sofia-1113, Bulgaria, e-mail: karazuzi@yahoo.com
}

\begin{abstract}
The microstructure and properties of spheroidal graphite cast irons and austempered ductile irons with nanosized additives of titanium carbonitride and titanium nitride (TiCN+TiN), titanium nitride TiN and cubic boron nitride cBN are investigated. The microstructure of the patterns is observed by optical metallography, quantity metallographic analysis, X-Ray analysis, SEM analysis and EDX analysis. Hardness measurement, impact strength and abrasion wear test on fixed abrasive are performed. The influence of the nanosized additives on the microstructure, mechanical and tribological properties of the cast irons are examined.
\end{abstract}

Keywords: spheroidal graphite iron, asutemepering, titanium nitride, titanium carbonitride, cubic boron nitride, wear resistance, hardness, structure, bainite, austenite.

\section{INTRODUCTION}

Spheroidal graphite cast iron is a structural material, characterized with a high strength, toughness and wear resistance. Graphite in the cast iron provides resistance to mechanical wear and improves the processability. Application of an alloying, thermal treatment or both of these processes influence the graphite morphology and substrate structure and allows achieving optimal properties of the iron [1-5]. Austempering is a thermal treatment process leading to a bainitic structure of the substrate material with high strength, increased ductility and high toughness [1-4]. The addition of small quantities of nanosized particles into the iron melt increases graphite quantity [9] and changes its morphology [8], which combined with the changes in the structure of the substrate enhances the wear resistance of the cast iron [7-10].

The aim of the present study is investigation of the microstructure, mechanical and tribological properties of spheroidal graphite cast iron and austempered ductile iron samples with nanosized additives of titanium carbonitride and titanium nitride ( TiCN+TiN), titanium nitride $\mathrm{TiN}$ and cubic boron nitride $\mathrm{cBN}$.

\section{MATERIALS AND METHODS}

The composition of the spheroidal graphite cast iron samples is: $\mathrm{Fe}-3,55 \mathrm{C}-2,67 \mathrm{Si}-0,31 \mathrm{Mn}-0,009 \mathrm{~S}-$ 0,027P-0,040Cu-0,025Cr-0,08Ni-0,06Mg wt $\%$. Samples with and without nanosized additives of titanium carbonitride and titanium nitride ( TiCN+TiN), titanium nitride TiN and cubic boron nitride $\mathrm{cBN}$ are investigated (Table 1). For the improvement of the particles wetting and their uniform distribution into the casting volume the electroless nickel coating is plated on the particles surface. EFTTOM-NICKEL method is used for electroless plating [11].

The microstructure of the spheroidal graphite cast iron samples is investigated by quantity metallography, scanning electronic microscopy (SEM), and Energy dispersive microanalysis (EDX). Scanning microscope EVO® MA10 „Carl Zeiss” with X-Ray micro analyzer „Bruker“ is used. The software „Olympus MicroImage" is used for the quantity metallographic analysis. Data for the average diameter $D_{\text {mid }}$ of the graphite particles, their roundness and the volume parts of the graphite, pearlite and ferrite are received.

The spheroidal graphite cast iron samples are subjected to the austempering, including heating at $900^{\circ} \mathrm{C}$ for an hour, after that isothermal retention at $280^{\circ} \mathrm{C}, 2 \mathrm{~h}$ and at $380^{\circ} \mathrm{C}, 2 \mathrm{~h}$. The austempered ductile iron samples' microstructure is observed by means of an optical metallographic microscope GX41 OLIMPUS. The samples surface is treated with 2 vol. $\%$ nital solution. The austempered ductile iron samples are tested by X-Ray diffraction analysis for measurement of the retained austenite quantity in the structure. The retained austenite quantity before and after abrasive wear is determined. X-ray powder http://dx.doi.org/ 10.17770/etr2017vol3.2605 
diffraction patterns for phase identification were recorded in the angle interval $20 \div 103^{\circ}(2 \theta)$, on a Philips PW 1050 diffractometer, equipped with $\mathrm{Cu}$ $\mathrm{K} \alpha$ tube and scintillation detector. Data for cell refinements and quantitative analysis are collected in $\theta-2 \theta$, step-scan mode in the angle interval from 20 to $103^{\circ}(2 \theta)$, at steps of $0.03^{\circ}(2 \theta)$ and counting time of 3s/step. Quantitative analysis is carried out by BRASS - Bremen Rietveld Analysis and Structure Suite [12].

The hardness test by Brinell method (for cast samples) and by Vickers method (for austempered samples) is performed. The impact strength test is carried out by a Charpy hammer.

The friction wear investigation on fixed abrasive by kinematic scheme "thumb-disc" is performed using accelerated testing [9, 10]. The impregnated material Smirdex 330 Duraflex P80, $117 S V$ is used for the spheroidal graphite cast iron. The test data are: nominal contact pressure $P_{a}=0,21.10^{6}[\mathrm{~Pa}]$; average sliding speed, $V=26,38 \quad[\mathrm{~cm} / \mathrm{s}]$; nominal contact surface, $A_{a}=50,24\left[\mathrm{~mm}^{2}\right]$; density, $\rho=7,80.10^{3}$ $\left[\mathrm{kg} / \mathrm{m}^{3}\right]$ [9]. The impregnated material Corundum 220 is used for the austempered ductile iron samples. The test data are: nominal contact pressure, $P_{a}=0,4.10^{6}$ [Pa]; average sliding speed, $V=24,5[\mathrm{~cm} / \mathrm{s}]$; nominal contact surface, $A_{\mathrm{a}}=50,24\left[\mathrm{~mm}^{2}\right] ;$ density, $\rho$ $=7,80.10^{3}\left[\mathrm{~kg} / \mathrm{m}^{3}\right][10]$.

\section{RESULTS AND DISCUSSION}

The structure of the tested iron after casting consists of ferrite, pearlite, and graphite [9]. The quantity metallographic analysis is performed for the evaluation of the influence of the nanosized particles on the graphite quantity, size and morphology. Also the quantity ratio between ferrite and pearlite is defined (Table 1). Nanosized additives in the spheroidal graphite cast iron don't change the graphite shape. They decrease the average diameter of the graphite sphere $D_{\text {mid }}$ from 11,00 to $10,34 \mu \mathrm{m}$ (Figure1). The increase of the quantity of the graphite phase with $35 \div 94 \%$ and the change of the pearlite and ferrite quantity in the iron structure (Table 1) are observed in the presence of the nanosized particles (Figure 2). The quantity ratio between structural elements with different hardness is changed (the pearlite hardness is highest and the graphite hardness is lowest). This is the reason for the changes in the total iron hardness (Table 1, Figure 3). The impact strength of the samples increases with $14 \div 37 \%$ for the irons with nanosized additives (Figure 4).

SEM analysis of the fracture of the impact destructed spheroidal graphite cast iron sample with TiCN+TiN nanoparticles additives (Figure 5) and EDX analysis of the graphite phase (Figure 6), show the nanoparticles presence in the graphite. These results and that achieved from the quantity metallographic analysis prove the modifying influence of the nanoparticles on the size and shape of the graphite phase in the iron samples.

In the wear resistance assessing of the iron base structure is necessary to take into account its ability to be changed as a result of a complex set of processes in operation. Graphite in the gray cast iron structure has an essential role in their wear. In case of dry friction virtually no wear was observed on some individual sections of the contact surface. This is related to the presence of graphite in the structure, which has a lubricating ability and acts as a lubricant material.

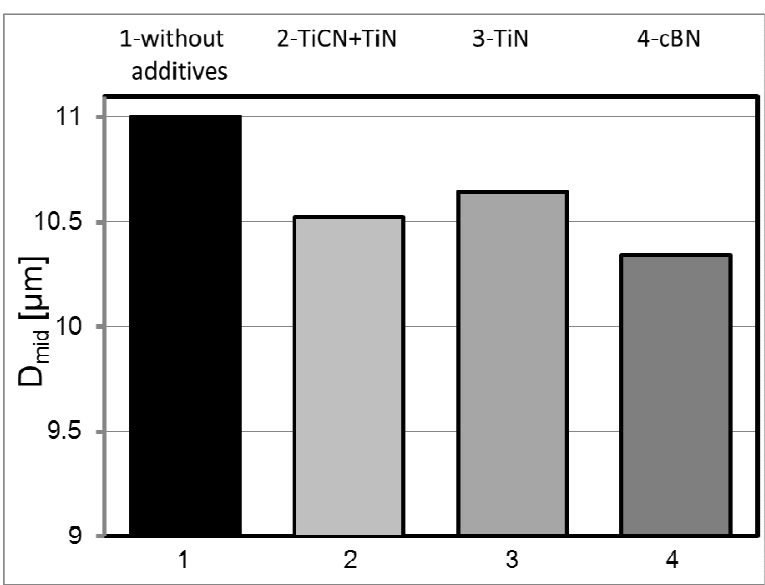

Figure 1. Average diameter of the graphite spheres Dmid in spheroidal graphite cast irons: 1,2, 3, 4- sample number

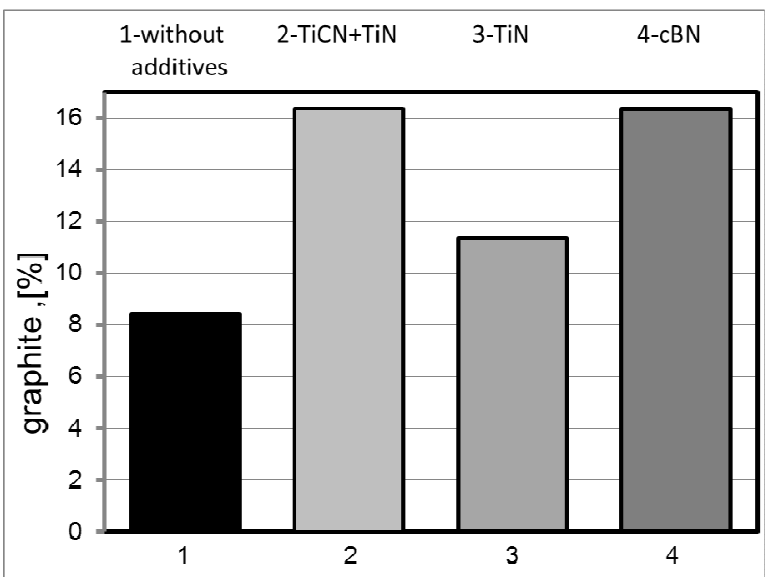

Figure 2. Graphite quantity in spheroidal graphite cast irons: 1,2, 3, 4 - sample number

The wear resistance of the irons with pearlite base at specified conditions of wear (contact pressure and sliding speed) is inversely proportional to the average distance between graphite grains. By reducing the distance between the graphite grains protective properties of the surface carbon layer is improved and the wear resistance of the iron is increased. 
Environment. Technology. Resources, Rezekne, Latvia

Proceedings of the $11^{\text {th }}$ International Scientific and Practical Conference. Volume III, 122-128

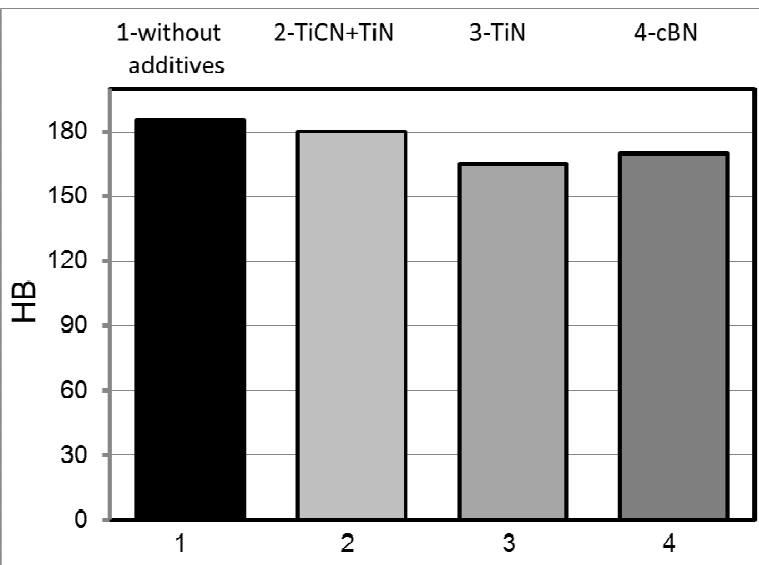

Figure 3. Hardness HB of spheroidal graphite cast irons: 1,2, 3, 4 sample number

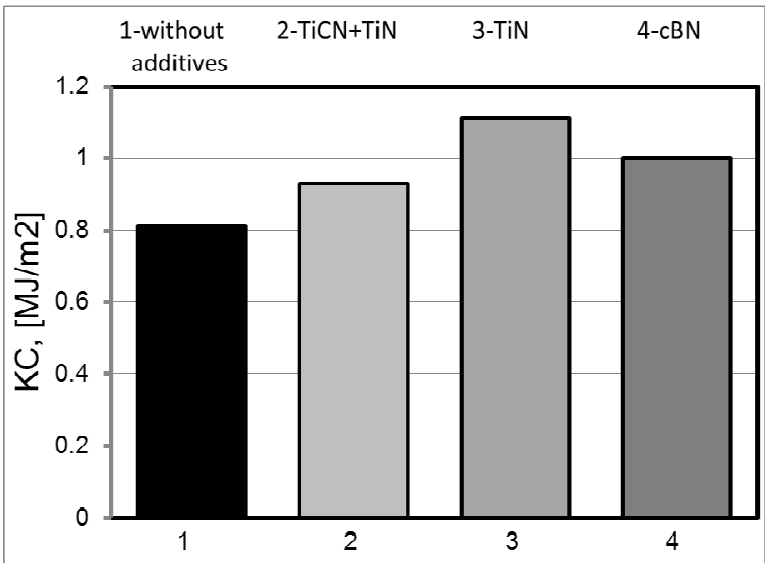

Figure 4. Impact strength $\mathrm{KC}$ of spheroidal graphite cast irons: 1,2, 3,4 - sample number
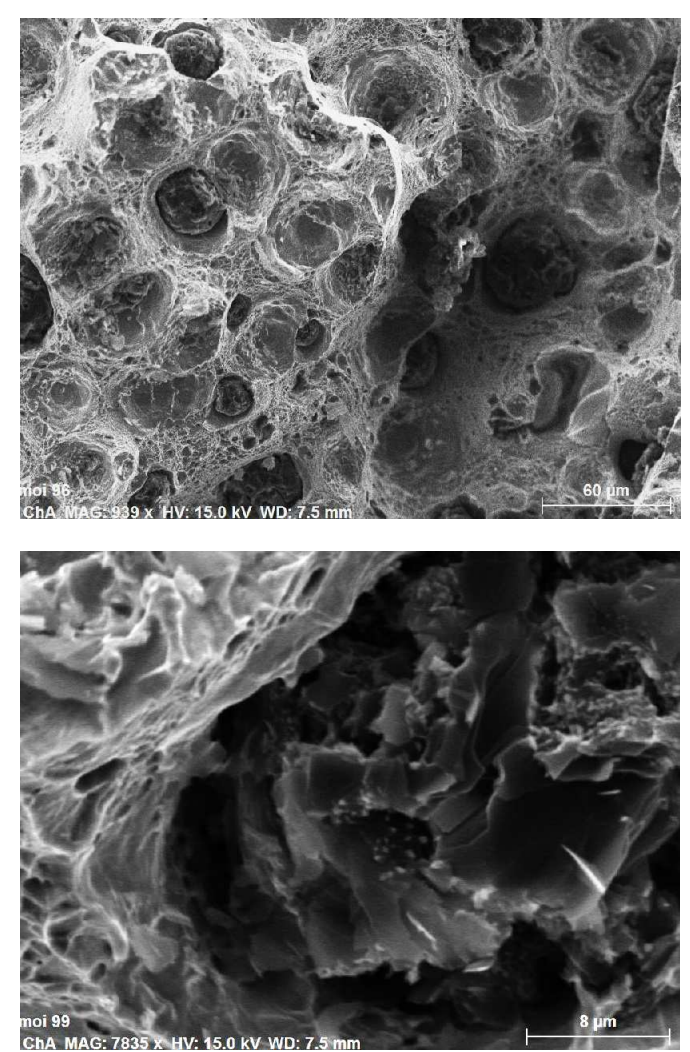

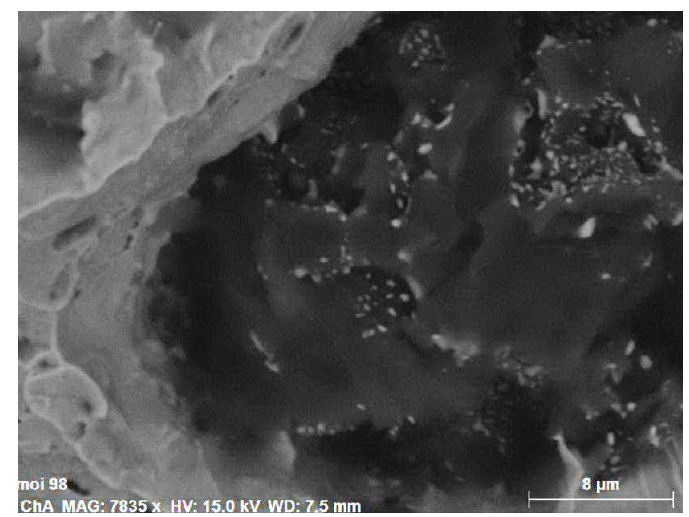

Figure 5. SEM analysis of the fracture of the impact destructed sample of spheroidal graphite cast irons with nanoadditives of TiCN+TiN (sample 2)

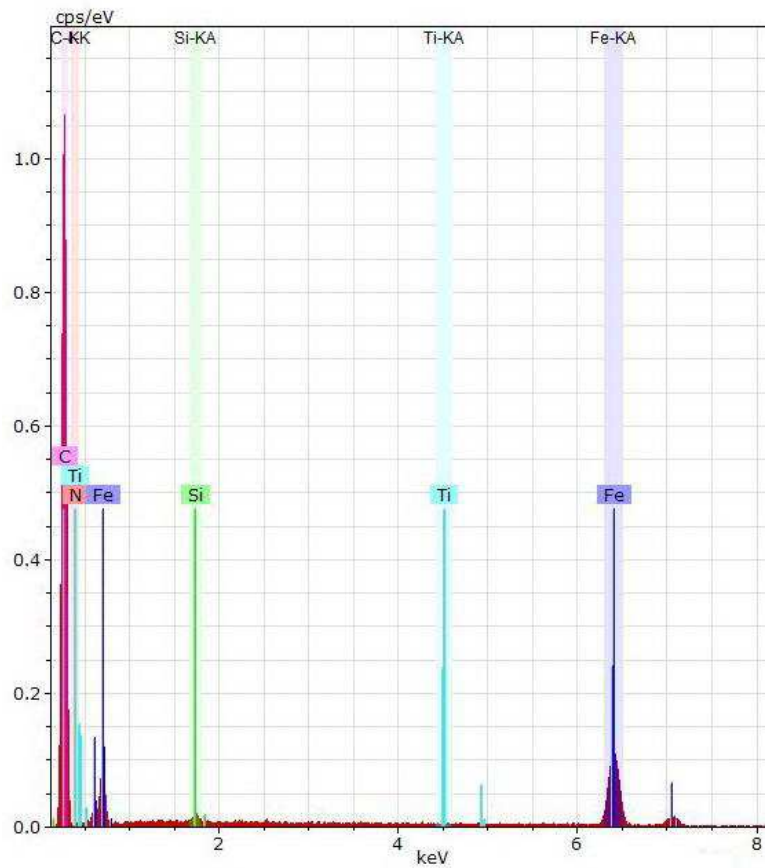

Figure 6. EDX analysis of the graphite phase of spheroidal graphite cast irons with nanoadditives of TiCN+TiN (sample 2)

Studied in this work spheroidal graphite cast iron with or without nanosized particles have an equilibrium ferrite-pearlite structure of the substrate and inclusions of graphite spheres [9].

The results of the quantitative metallographic analysis show that the nanosized additives without changing the graphite shape, increase its volume and decrease the average diameter of the graphite spheres (Figures 1 and 2), which leads to a reduction of the average distance between the graphite grains. Wear resistance of the cast iron with nanoadditives increase by $55 \div 88 \%$ compared to this one of the cast iron without nanoparticles (Figure 7). 


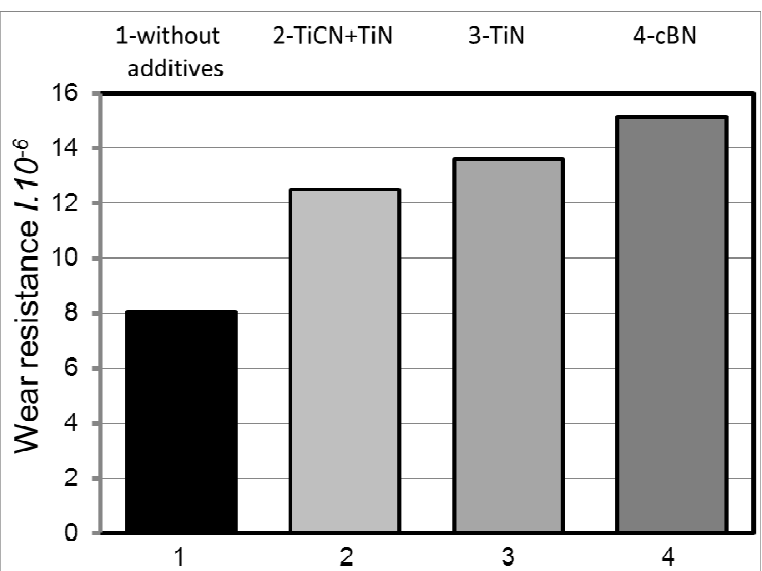

Figure 7. Wear resistance I of spheroidal graphite cast irons: 1,2, 3,4 - sample number

The spheroidal graphite cast irons without and with nanoparticles are undergone to austempering with the aim to receive a bainitic structure of the metal substrate. The austempering mode includes austenitization at $900^{\circ} \mathrm{C}, 1 \mathrm{~h}$ followed by austempering at $280^{\circ} \mathrm{C}, 2 \mathrm{~h}$ and at $380^{\circ} \mathrm{C}, 2 \mathrm{~h}$. As a result of this thermal treatment cast iron structure obtained lower bainitic (Fig. 8) or upper bainitic structure (Fig. 9).

Bainite is an oriented structure consisting of needles $\alpha$ - phase (bainitic ferrite), carbides and unconverted austenite. $\alpha$-phase is formed by martensitic mechanism in austenitic areas with low carbon content $[1,2,10]$. Upon cooling on the temperature of isotherm to ambient temperature, the part of the unconverted austenite undergoes martensitic transformation, and another part thereof remains in the structure as retained austenite $\mathrm{A}$. The austenite bainitic transformation begins with the formation of individual needles $\alpha$-phase (bainitic ferrite) and is developed with the formation of new oriented needles located close to each other and forming a package of alternating plates $\alpha$-phase and the unconverted austenite enriched with carbon A (c) $[1,2,10]$.
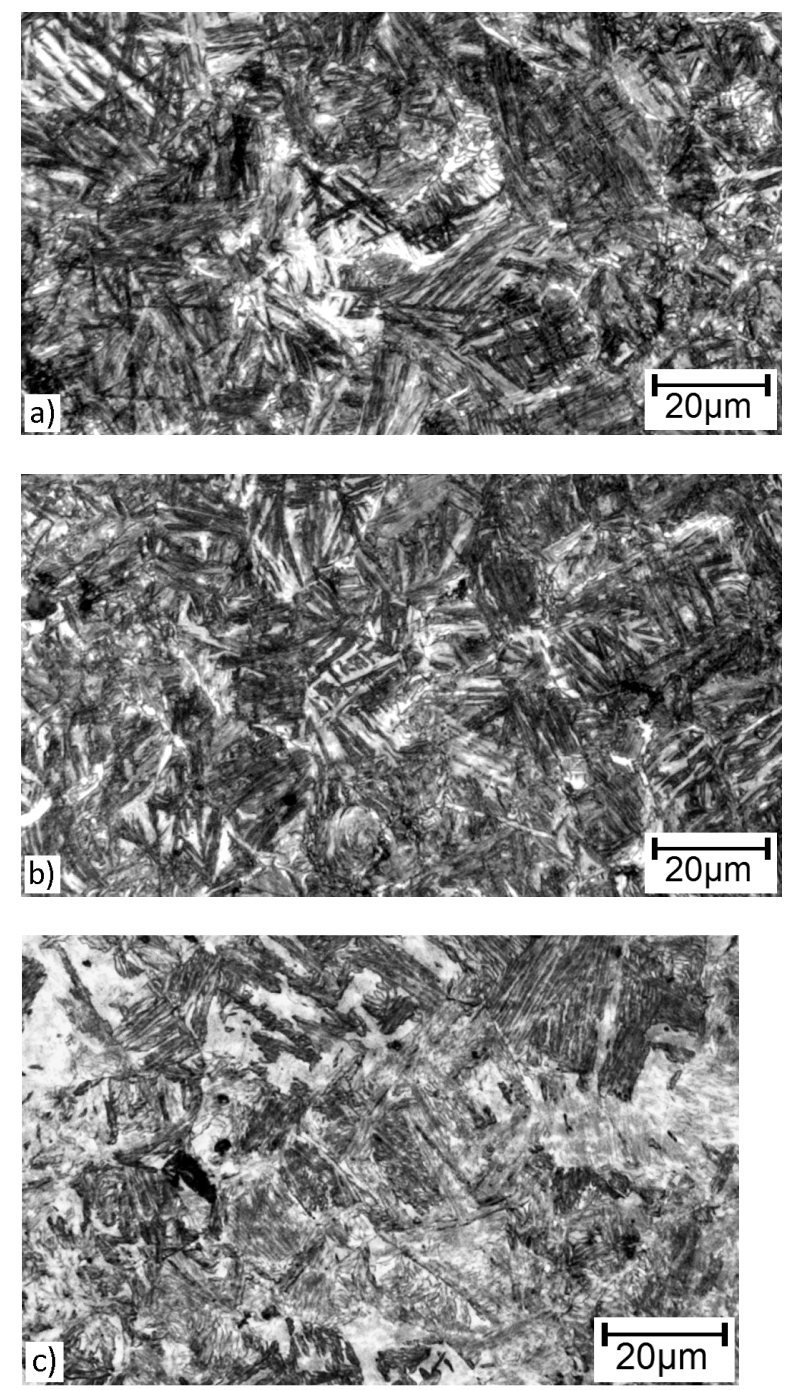

Figure 8. Lower bainite in austempered spheroidal graphite cast irons: a -sample 5; b-sample 6; c- sample 8

TABLE 1.

Nanoadditives, graphite characteristics, graphite, pearlite and ferrite quantity and mechanical properties of spheroidal graphite

\begin{tabular}{|c|c|c|c|c|c|c|c|c|c|}
\hline \multirow{2}{*}{$\begin{array}{c}\text { № } \\
\text { of } \\
\text { sample }\end{array}$} & \multirow{2}{*}{$\begin{array}{c}\text { Nanosized } \\
\text { additive }\end{array}$} & \multirow{2}{*}{$\begin{array}{c}\mathrm{D}_{\text {mid }} \\
\mu \mathrm{m}\end{array}$} & \multirow{2}{*}{ Roundness } & \multicolumn{3}{|c|}{ Volume part of: [\%] } & Hardness & $\begin{array}{c}\text { Impact } \\
\text { strength } \\
\text { KC } \\
\mathrm{MJ} / \mathrm{m}^{2}\end{array}$ & $\begin{array}{c}\text { Wear } \\
\text { resistance } \\
I\end{array}$ \\
\hline 1 & - & 11,00 & 1,59 & 8,44 & 32,12 & 59,44 & 185 & 0,81 & $8,06.10^{6}$ \\
\hline 2 & TiCN+TiN & 10,52 & 1,28 & 16,36 & 25,36 & 58,28 & 180 & 0,93 & $12,5.10^{6}$ \\
\hline 3 & $T i N$ & 10,64 & 1,49 & 11,36 & 34,28 & 54,36 & 165 & 1,11 & $13,6.10^{6}$ \\
\hline 4 & $c B N$ & 10,34 & 1,23 & 16,34 & 35,74 & 47,92 & 170 & 1,0 & $15,15.10^{6}$ \\
\hline
\end{tabular}



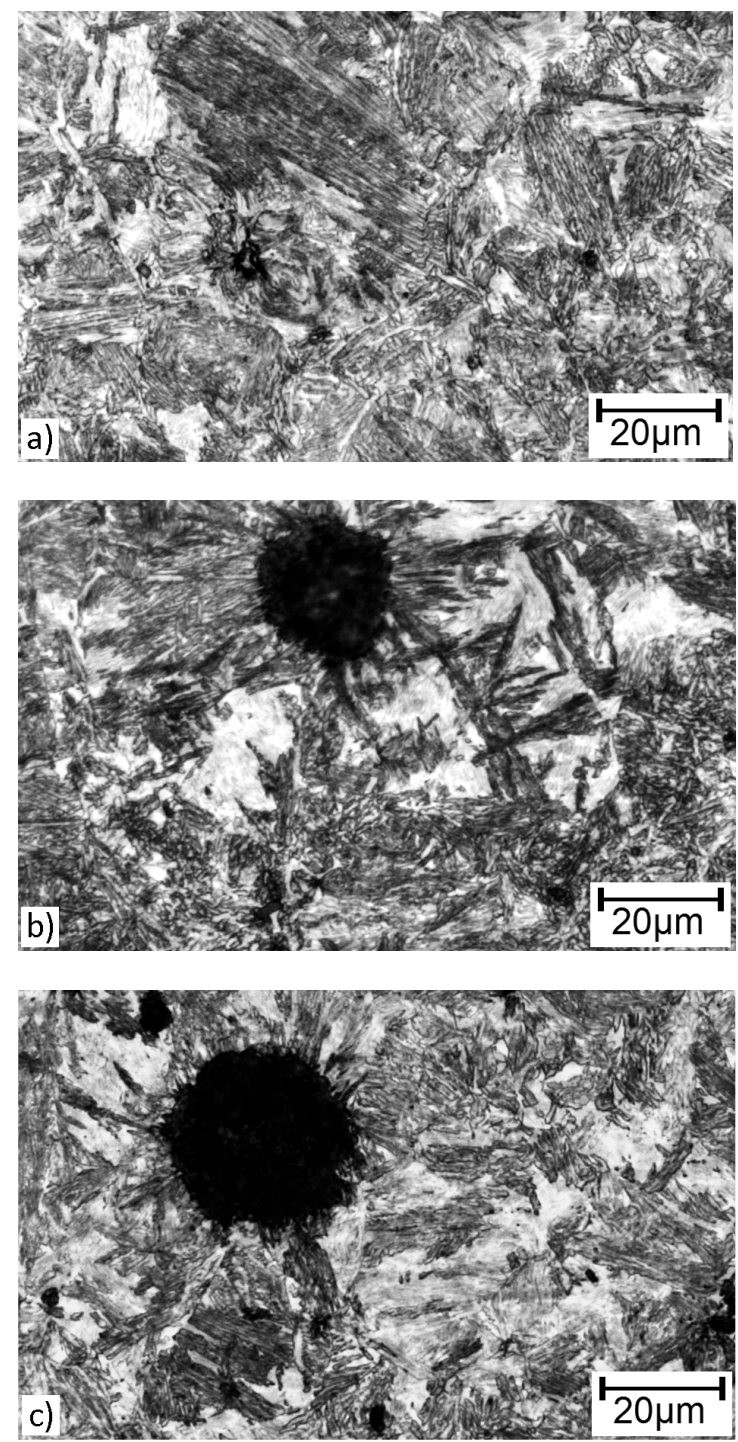

Figure 9. Upper bainite in austempered spheroidal graphite cast irons: a -sample 9; b- sample 10; c-sample 11

Optical metallographic analysis shows this package as individual needle in the lower bainitic struicture. Carbide phase is formed as a result of selftempering of the $\alpha$-phase or directly from $\mathrm{A}(\mathrm{c})$. Silicon in the spheroidal graphite irons (2-3\%) hinders process of the carbide formation. Bainitic ferrite and enriched with carbon unconverted austenite A(c) structures with high mechanical characteristics are realized at austempering 2-4 hours. An austempering mode over 6 hours could lead to a decomposition of the enriched with carbon austenite to a composite of ferrite and carbide ( $\alpha+$ carbide), which decreases the iron mechanical properties and in practice not be carried out.

The lower bainitic structure hardness HV10 is in the range of $388-422 \mathrm{HV} 10$, whereas this one of the upper bainite is - 312 - 319 HV10 (Table2, Figure 10). The higher upper bainitic hardness is correlated to the higher carbon saturation of the $\alpha$-phase and to the higher degree of the austenite transformation in the lower temperature range of the bainitic area.

The quantity of the retained austenite in the samples with upper bainitic structure is higher than this one in the samples with the lower bainitic structure. This correlates with the characteristics of the bainitic transformation mechanism in the upper and lower range of the bainitic area (Figure 11). The higher quantity of the retained austenite in the samples with upper bainitic structure defines their higher impact strength compared to this one of the samples with lower bainitic structure (Figure 12).

The wear resistance of the samples with nanosized additives of $\mathrm{TiCN}+\mathrm{TiN}$ and structure of lower bainite is $73 \%$ higher compared to this one of the samples without nanoadditives. The increase of the wear resistance of the samples with the same additives and an upper bainitic structure is $27 \%$ higher (Figure 13). The quantity of the retained austenite in the austempered samples before and after tribological testing is defined by X-Ray analysis (Table 2). It is found that the retained austenite quantity decreases in all of the samples after tribological testing (Figure 11).

The reduction of the retained austenite quantity is in the greatest extent in the samples with nanoadditives of TiCN+TiN. They possess highest wear resistance (Figure 13). The tribological properties of the metal materials largely depend on the structural condition forming on the contact surface in the friction process. The retained austenite in the austempered ductile irons' structure is a metastable structure and by friction impact could be undergone strain inducing $\gamma \rightarrow \alpha$ martensitic transformation. Friction partially transforms retained austenite in strain induced martensite consisting the same quantity carbon as well as high carbon austenite and appears untampered martensite with high hardness and possibility for intensive strengthening wear [10]. The formation of the strain induced martensite from the metastable retained austenite in the area of the friction contact probably is one of the reasons for the wear resistance increase of these irons.

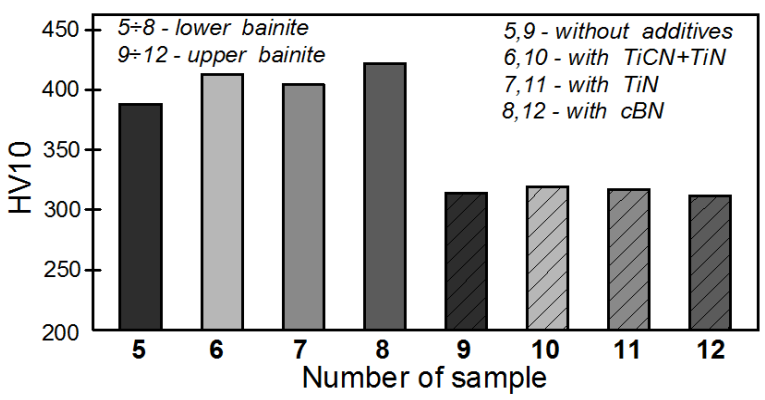

Figure 10. Hardness HV10 of austempered spheroidal graphite cast irons with lower bainitic structure (samples 5,6,7,8) and upper bainitic structure (samples 9,10,11,12) 


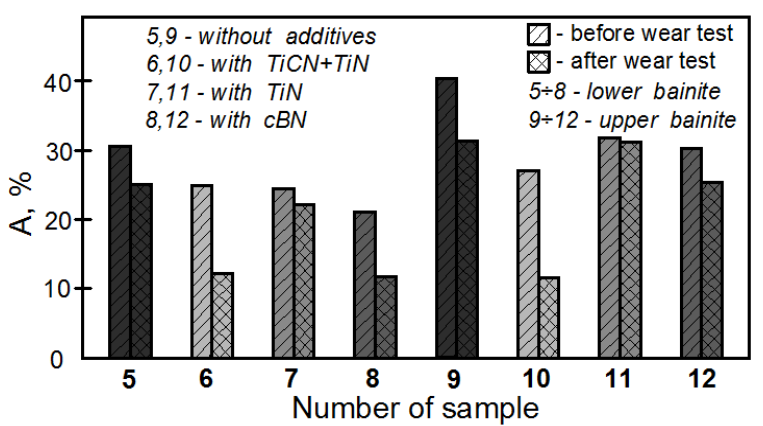

Figure 11. Retained austenite quantity $\mathrm{A}$ in austempered spheroidal graphite cast irons with lower bainitic structure (samples $5,6,7,8$ ) and upper bainitic structure (samples 9,10,11,12) before and after tribological testing

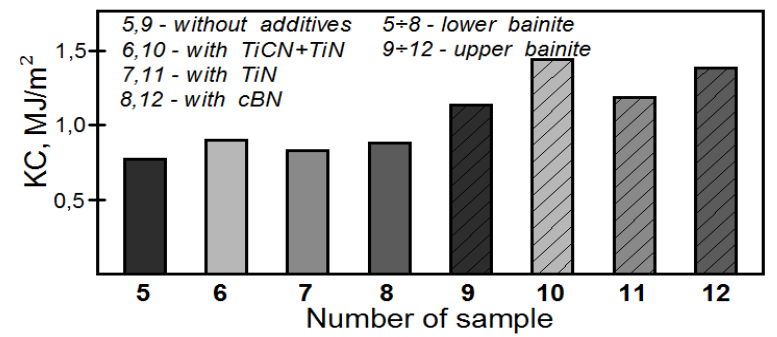

Figure 12. . Impact strength $\mathrm{KC}$ of austempered spheroidal graphite cast irons with lower bainitic structure (samples 5,6,7,8) and upper bainitic structure (samples 9,10,11,12)

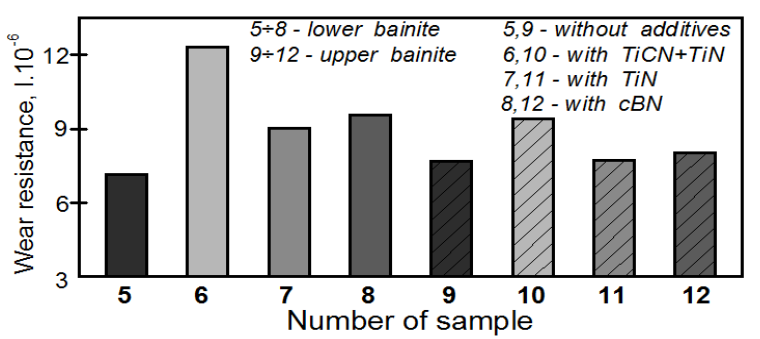

Figure 13. Wear resistance I of austempered spheroidal graphite cast irons with lower bainitic structure (samples 5,6,7,8) and upper bainitic structure (samples 9,10,11,12)

Table 2.

Nanoadditives, hardness, impact strength, wear resistance and retained austenite of austempered ductile iron (ADI)

\begin{tabular}{|c|c|c|c|c|c|c|c|}
\hline \multirow{2}{*}{$\begin{array}{c}\text { № } \\
\text { of } \\
\text { sample }\end{array}$} & \multirow{2}{*}{ Structure } & \multirow{2}{*}{$\begin{array}{l}\text { Nanosized } \\
\text { additive }\end{array}$} & \multirow{2}{*}{$\begin{array}{c}\text { Hardness } \\
\text { HV10 }\end{array}$} & \multirow{2}{*}{$\begin{array}{c}\text { Impact } \\
\text { strength } \\
\mathrm{KC} \\
\mathrm{MJ} / \mathrm{m}^{2}\end{array}$} & \multirow{2}{*}{$\begin{array}{c}\text { Wear } \\
\text { resistance } \\
\text { I }\end{array}$} & \multicolumn{2}{|c|}{ Retained austenite A,\% } \\
\hline & & & & & & before wear test & after wear test \\
\hline 5 & \multirow{4}{*}{ lower bainite } & - & 388 & 0,771 & $7,13.10^{6}$ & 30,6 & 25,0 \\
\hline 6 & & $T i C N+T i N$ & 413 & 0,901 & $12,3.10^{6}$ & 24,9 & 12,2 \\
\hline 7 & & $T i N$ & 405 & 0,828 & $9,03.10^{6}$ & 24,4 & 22,1 \\
\hline 8 & & $c B N$ & 422 & 0,884 & $9,56.10^{6}$ & 21,0 & 11,8 \\
\hline 9 & \multirow{4}{*}{ upper bainite } & - & 314 & 1,137 & $7,67.10^{6}$ & 40,4 & 31,3 \\
\hline 10 & & $T i C N+T i N$ & 319 & 1,442 & $9,42.10^{6}$ & 27,1 & 11,6 \\
\hline 11 & & $T i N$ & 317 & 1,190 & $7,72.10^{6}$ & 31,8 & 31,2 \\
\hline 12 & & $c B N$ & 312 & 1,387 & $8,03 \cdot 10^{6}$ & 30,2 & 25,3 \\
\hline
\end{tabular}

\section{CONCLUSION}

The microstructure, hardness, impact strength and wear resistance of the spheroidal graphite cast irons and austempered ductile irons without and with nanosized additives of titanium carbonitride and titanium nitride $(\mathrm{TiCN}+\mathrm{TiN})$, titanium nitride $\mathrm{TiN}$ and cubic boron nitride $\mathrm{cBN}$ are investigated.

Nanosized additives in the spheroidal graphite cast irons have a modifying effect on the graphite phase. They don't change the graphite shape, but decrease the graphite spheres size and increase the graphite quantity in the irons' structure. Spheroidal graphite cast irons with nanosized additives have a higher abrasion resistance and higher impact strength compared to the irons without nanoparticles.

Nanosized additives in the austempered ductile irons change the bainitic transformation kinetic and accelerate the austenite transformation to bainite. The austempered ductile irons with nanoadditives have higher impact strength and higher abrasion resistance compared to the samples without nanoadditives. The partially transformation of the metastable retained austenite to strain induced martensite by friction impact in the greatest extent occurs in the irons with nanoadditives of $\mathrm{TiCN}+\mathrm{TiN}$, which influence on their wear resistance. 
Environment. Technology. Resources, Rezekne, Latvia Proceedings of the $11^{\text {th }}$ International Scientific and Practical Conference. Volume III, 122-128

\section{REFERENCES}

[1] Dorasil E. High-strenght Bainitic Nodular Cast Iron. Prague, Academia, 1985, $170 \mathrm{p}$

[2] Bhadeshia H.K.D.H. Bainite in Steels, 2 nd ed., Inst. of Materials, Cambridge, London, 2001, 460p.

[3] A.S.M.A. Haseeb, Md.A. Islam, Md.M.A. Bepari, Tribological behavior of quenched and tempered, and austempered ductile iron at the same hardness level, Wear 244 (2000) 15-19.

[4] Y. Sahin, M. Erdogan, V. Kilicli, Wear behavior of austempered ductile irons with dual matrix structures, Mater. Sci. Eng. A 444 (2007) 31-38.

[5] W. Xu, M. Ferry, Y. Wang, Influence of alloying elements on as cast microstructure and strength of gray iron, Mater. Sci. Eng. A 390 (2005) 326-333.

[6] K. Hirasata, K. Hayashi, Y. Inamoto, Friction and wear of several kinds of cast irons under severe sliding conditions, Wear 263 (2007) 790-800.

[7] J. Li, M. Chen, H. Gao, Y. Zhao, Structures and Properties of Cast Irons Reinforced by Trace Addition of Modified SiC
Nanopowders. Chinese Journal of Chemical Physics, Vol.20, No 6 (2007) $625-631$.

[8] Y. Wang, Z. Pan, Z. Wang, X. Sun, L. Wang, Sliding wear behavior of $\mathrm{Cr}-\mathrm{Mo}-\mathrm{Cu}$ alloy cast irons with and without nanoadditives, Wear 271 (2011) 2953- 2962.

[9] Kaleicheva J., M. Kandeva, V. Mishev, Z. Karaguiozova. Wear Behavior of Ductile Cast Irons with Nanoparticle Additives. J. Chem. Chem. Eng., Vol. 7, No 11, (2013), p. 1044-1049.

[10] Kaleicheva J., V. Mishev, G. Avdeev, Z. Karaguiozova, B. Dineva. Influence of Nanoadditives on the Structure and Properties of Austempered Ductile Irons. European Conference on Heat Treatment and 21st IFHTSE Congress, 12-15 May 2014, Munich, Germany, 2014, p. 537-543.

[11] Gavrilov G., C. Nicolov. Electroless Nickel and Composite Coatings, Tehnika, Sofia, 1985.

[12] BIRKENSTOCK, J., FISCHER, R.X., MESSNER, T. (2003): BRASS 2003: The Bremen Rietveld Analysis and Structure Suite. Ber. DMG, Beih. z. Eur. J. Mineral. 15(1), 21 